\title{
Harp seal heart valves being tested for human use
}

$\mathrm{R}$ esearchers in Quebec will soon begin testing heart valves from harp seals to determine if they are suitable for use in humans.

Animal rights groups say the research is unnecessary and will serve only as a government propaganda tool to promote Canada's sealing industry, which received a major blow on May 5 when Europe banned imports of seal products. The federal government projects that a commercial seal valve market could generate substantial revenue for Canada, but heart valve experts involved in the project say the research could lead to more than just financial gain. If their theory is proven true - if seal valves do offer significant advantages over existing bioprosthetic valves - the research could result in prolonged and improved lives for sufferers of heart valve disease.

"I'm optimistic that it could be superior to bovine or porcine valves," says Philippe Pibarot, Canada research chair in valvular heart diseases.

Over the next 3 years, Pibarot and his colleagues will conduct proof-ofconcept research at the Quebec Heart and Lung Institute in Québec City. They will collaborate with $\mathrm{Ta} \mathrm{Ma} \mathrm{Su}$ Inc., a Québec City-based producer of seal products, and Laboratoires Perouse, a company in France that makes products for cardiovascular surgery and oncology. Also involved is Dr. Andreas Agathos, a cardiac surgeon in Athens, Greece, who holds several patents on a method of replacing human valves with marine mammal valves.

Pibarot, a medical professor at Université Laval in Québec City, obtained harp seal valves from Ta Ma Su Inc. in March 2008. He hopes to test seal valves in animals, possibly sheep, within 3 years. Though human implantation may be 8 to 10 years away, Pibarot says the limited durability of valves made from pig and cow tissue makes this research necessary. "The anatomy and structure of seal valves are different. Their valves are thicker with

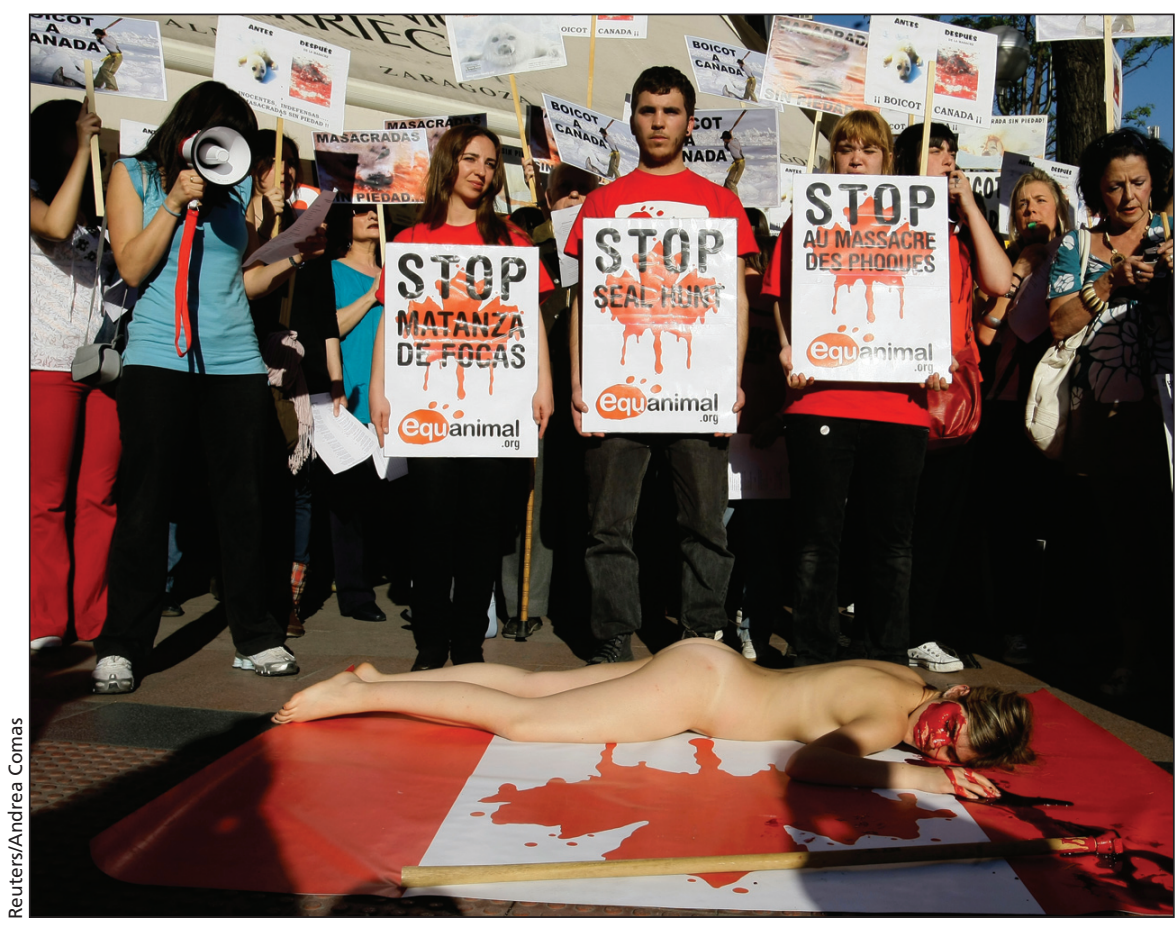

Animal rights activists protest in Madrid, Spain, against Canada's seal hunt.

more elastic fibres. They have a more robust structure because they are designed by Mother Nature to survive harsher conditions."

David Lavigne, science adviser for the International Fund for Animal Welfare, says he's heard this story before. "We roll our eyes every time it comes up," says Lavigne, who for 23 years taught zoology at the University of Guelph in Guelph, Ontario. "It doesn't seem very likely — or very necessary."

Lavigne, who has studied seals since 1969 , says he is unaware of a demand for more bioprosthetic valves. Harp seals carry bacteria and viruses that could prove harmful to humans, he adds, and talk of harvesting seal valves only seems to arise during Canada's annual - and controversial - seal hunt. A commercial seal valve market could eventually require about 300000 seals a year, according to Agathos. The quota for Canada's 2009 hunt is 280000 .

"It seems to be a remarkable coincidence that Dr. Agathos' perceived needs nearly matches the allowable catch," says Lavigne.

Also of concern to Lavigne is the inclusion in Agathos' patents of several near-extinct marine mammals, such as the Mediterranean Monk Seal. Lavigne says Agathos has yet to release any evidence that seal valves are superior to existing valves, even though the Greek doctor first tested them in the 1990s and has spoken about his research in the media several times. "You don't do research by press release or media interviews or propaganda from the federal Department of Fisheries and Oceans."

Agathos says he has ample scientific evidence to back his claims, and that it will be made public sometime in the next year, after he applies for a licence to conduct clinical trials. He had wanted to conduct trials in Greece, where he is the director of cardiac surgery at Athens Medical Centre, but because of the European ban will have to conduct them elsewhere - possibly in Canada. 
"What happened in Europe was totally stupid," says Agathos, who on Mar. 23 wrote a letter protesting the ban to the European Union Environment Council. "They decided for physicians what will be the best treatment. ... I strongly believe that this will be the best valve on the market, and we are going to replace all the other valves."

Agathos began testing marine mammal valves about a decade ago in the United States, where he worked with Dr. Albert Starr, a world-renowned pioneer in artificial heart valves. He tested the valves of whales, dolphins and porpoises but found that seal valves were most similar to human valves.

People with heart valve disease currently have 3 replacement valve options: valves from cadavers (not widely used because of problems with sterilization, storage and availability), mechanical valves and animal tissue valves (porcine aortic and bovine pericardial).

Younger patients generally receive mechanical valves because they are more durable than bioprosthetic valves. The downside is that these patients are at high risk of developing thromboembolism and must take anticoagulation there is no calcification. We are talking about the ideal valve," says Agathos, who has also developed a bioprosthesis from seal tracheas that he says could be used to replace damaged or deformed human tracheas.

According to Pibarot, seal hearts offer several other advantages as well. From pig hearts, only the aortic valves can be used; from a seal heart, transplantable valves can be made from the aortic valve, the pulmonary valve and the pericardium. Another problem with pig valves is that they have a "muscle shelf" that is predisposed to calcification and partially obstructs blood flow. Fixing this requires using parts of another pig valve.

"You can take 1 valve from a seal and make 1 valve for a human," says Pibarot. "You need 2 pig valves to make 1 valve for a human."

Except for Agathos and the Quebec researchers, there appear to be few heart valve experts who know anything about seal valves. CMAJ contacted several well-known heart institutions and those that responded said they had no one qualified to comment. CMAJ also sought comment about seal valves from Edwards Lifesciences, a 6200-

\section{Heart valves from seals "have a more robust structure because they are designed by Mother Nature to survive harsher conditions." - Philippe Pibarot}

medicine for the remainder of their lives. Most people with valves made from animal tissue don't need to take blood thinners, but this advantage is offset by a significant problem - biological valves calcify over time.

The resulting tissue deterioration means the valves could start to fail within 5 years and will almost certainly need to be replaced within a decade. And that means another major surgery for someone whose heart has already been through a lot. Seal valves would solve this problem, Agathos says, because they are full of omega-3, a natural anticalcification treatment.

"This is a biological valve. Plus employee company based in California that touts itself as "the global leader in the science of heart valves and homodynamic monitoring." (It reported US\$1.24 billion in sales in 2008.) In an email, Sarah Huoh, the company's senior manager of global communications, said that "Edwards has not as a company done any research in the area."

Two Canadians who are familiar with Agathos' research are Bernard Guimont, president of $\mathrm{Ta} \mathrm{Ma} \mathrm{Su} \mathrm{Inc.,} \mathrm{and}$ Loyola Sullivan, Canada's ambassador for fisheries conservation. Ta Ma Su Inc. has provided Agathos with about 300 seal hearts over the past 2 years. Guimont has also been in contact with the

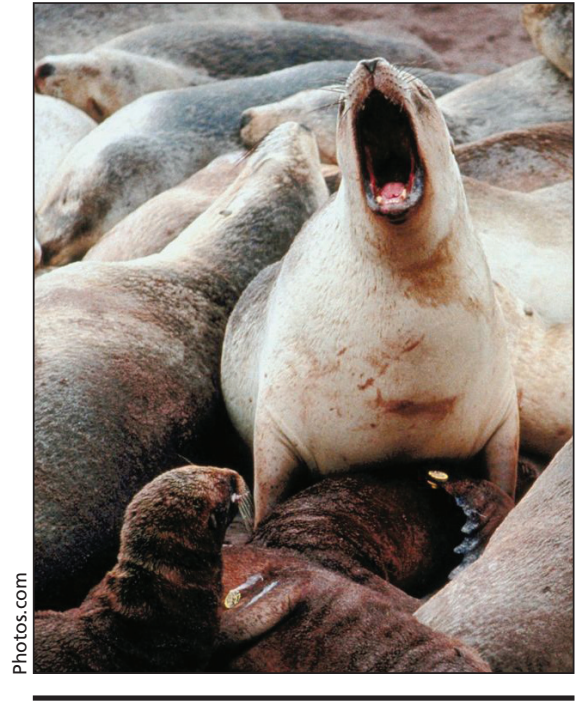

The harp seal quota for the 2009 hunt in Canada is 280000 .

Université Laval researchers and is encouraged by their project's progress.

"We feel that there is tremendous opportunity, but there is still a lot of work to do," he says. "Here you have an animal that is overpopulated with no predator in its environment. Instead of just doing pest control, we have a fantastic opportunity to control the population but also to eventually save lives."

Sullivan says that contrary to the opinion of animal activists, the government is not promoting the harvesting of seal valves to make the seal hunt more palatable to the public, though it does encourage the research. With an estimated cost of $\$ 5000$ each, and considering there are about 300000 valve transplants worldwide each year, a commercial seal valve market would be very good for Canada, says Sullivan. "Even on a conservative scale, it would be a few hundred million."

If the European ban persists, however, the global market for seal valves would have a sizeable hole. Since the European ban includes omega-3-rich seal oil capsules, it seems unlikely that exceptions would be made for other medical products, such as heart valves. "I can't see how they would treat this any differently," says Sullivan, "unless Europe becomes more informed and makes decisions based on facts and science, and not on emotion." - Roger Collier, CMAJ

DOI:10.1503/cmaj.090936 